\title{
Team Loving and Loathing: Emotional Determinants of Consumption in Collegiate Football
}

\author{
Harry A. Taute \\ Utah Valley University \\ Jeremy J. Sierra \\ Texas State University-San Marcos \\ Robert S. Heiser \\ University of Southern Maine
}

The popularity of collegiate football in America is unprecedented. The fan frenzy surrounding teams, games, and the sport itself, is borderline barmy. Aptly described as the thrill of victory and the agony of defeat, fan emotions in college football are rampant; yet, research exploring such hedonic-related consumption is scant. To help close this gap, two studies, grounded in Mehrabian \& Russell's (1974) pleasure, arousal, and dominance (PAD) typology of emotions, were developed to help explain collegiate football sport consumption for loved and loathed teams. Study 1 examined PAD emotional determinants of fans' purchase intentions and willingness to attend games of their favorite team. The findings indicated that the emotional dimension of arousal related positively with fans' apparel and memorabilia purchase intentions and willingness to attend games; also, the pleasure and dominance emotional dimensions related positively to purchase intentions of apparel and memorabilia, respectively. Study 2 explored PAD emotional determinants of fans' willingness to attend games involving their least favorite team. The findings revealed significant positive effects for the emotional dimensions of pleasure, arousal, and dominance on willingness to attend collegiate football games. Implications for sports marketers and future research suggestions are offered.

Emotions have long been considered antecedents of, critical to, and primary outcomes of consumption experiences (Loewenstein, Weber, Hsee, \& Welch, 2001; MacInnis \& de Mello, 2005); such emotions may be especially poignant

Taute is with the Woodbury School of Business, Utah Valley University, Orem, UT. Sierra is with the Marketing Dept., McCoy College of Business Administration, Texas State University-San Marcos, San Marcos, Texas. Heiser is with the School of Business, University of Southern Maine, Portland, ME. 
in intercollegiate rivalries where a long history of bitterly fought contests involve several generations of love/hate relationships. Along these lines, prior sports marketing research has focused on emotional involvement and attachment as drivers of sport consumption, and measured emotional attachment with items indicative of loyalty and fanaticism (e.g., Koo \& Hardin, 2008; Robinson, Trail, \& Kwon, 2004; Trail, Robinson, Dick, \& Gillentine, 2003). Although insightful, this perspective seemingly masks or ignores the underlying approach/avoidance behaviors associated with basic emotions (Elster, 1998). As a result, this view largely discounts how particular emotional dimensions (e.g., arousal) influence sport consumption.

In contrast, the current research examines factors of Mehrabian and Russell's (1974) emotional framework as determinants of collegiate football consumption for loved and loathed teams. In doing so, we posit sport consumption as a hedonicladen, experiential consumer context (Hirschman \& Holbrook, 1982; Holbrook \& Hirschman, 1982), characterized by pleasure, arousal, and dominance-type fan emotions, which influence purchase decisions. Hence, game attendance, apparel purchase, and memorabilia acquisition are intrinsically motivated by internal feelings for a team as well as the desire for multisensory, emotive experiences (Hirschman \& Holbrook, 1982; Holbrook, Chestnut, Oliva, \& Greenleaf, 1984).

Our research proceeds by first examining the extant sports literature concerning drivers of game attendance, purchasing and wearing of apparel, and acquiring of sports memorabilia as the contextual background for our research. Second, we review literature on concurrent and resulting consumption emotions and how such emotions might be measured in sports contexts. In an effort to explain how emotions may actually be a strong predictor of attendance where a rival is concerned, a discussion of how tribal behavior aptly describes and explains emotions against the least favorite team ensues. We then describe the relationship(s) between the pleasure, arousal, and dominance (PAD) typology of emotions (Mehrabian \& Russell, 1974; Russell \& Mehrabian, 1977), for fans' favorite (Study 1) and least favorite (Study 2) college football teams on sport consumption using regression analysis. Our manuscript concludes with a discussion of the results, implications, and future research suggestions.

\section{Literature Review}

\section{Determinants of Game Attendance}

Among factors found to influence attendance at sporting events are family and friends (i.e., social networks) (Wakefield, 1995), sport interest and team identification or attachment (Fisher, 1998; Funk, Mahony, \& Ridinger, 2002; Mahony, Nakazawa, Funk, James, \& Gladden, 2002; Matsuoka, Chelladurai, \& Harada, 2003), fan loyalty and involvement (Funk \& James, 2001; Hill \& Green, 2000; Mahony, Madrigal, \& Howard, 2000), eustress (i.e., anxiety and excitement regarding athletic events) (Swanson, Gwinner, Larson, \& Janda, 2003), division of competition (e.g., Football Bowl Subdivision-FBS) (Robinson, Trail, Dick, \& Gillentine, 2005), and a good (competitive) game (Trail et al., 2003). Regarding type of game attendee, distinctions may drawn between emotionally attached fanatics (e.g., Koo \& Hardin, 2008), fans involved with the sport or team (Mahony et al., 2002; Robinson et al., 
2005), and spectators drawn by the excitement, drama, and excellence of the contest (Matsuoka, Chelladurai, \& Harada, 2003). Thus, emotions or emotional proxies should help explain why fans attend games. Therefore, we offer an initial look at how the emotional model of pleasure, arousal, and dominance affects intentions to attend college football games for loved and loathed teams.

\section{Determinants of Team Apparel and Memorabilia Purchases}

The team-licensed merchandise industry is lucrative, and affords fans a means to express their team support, further solidifying their uniqueness in society (Fowler, 1999). Factors shown to influence such purchases include team identification and perceived value (Kwon, Trail, \& James, 2007), and attitudes toward sport-related promotions (Karayianni \& Mylonakis, 2008). Team success also can explain apparel purchases in that when a college football team wins, its fans are more likely to bask in reflected glory (BIRG) and wear team apparel than if their team loses (Cialdini et al., 1976). To build on these findings, we offer a preliminary examination of PAD effects on college football apparel and memorabilia purchases.

\section{Consumption Emotions}

Experienced emotions are integral to understanding consumer behavior in a variety of situations, including sports contexts (Preuss, 2007; Raynaud \& Bolos, 2008). For example, high team identification fans experience more positive emotions after a team win than loss, which may ultimately lead to team allegiance (Bizman \& Yinon, 2002). In other contexts like gift giving and receipt, donors and recipients report a wide range of positive and negative emotions before, during, and after the occasion (Ruth, 1996; Ruth, Otnes, \& Brunel, 1999). In retail shopping contexts, consumers may monitor feelings as approach/avoidance indicators (Pham, 2004; Pham, Cohen, Pracejus, \& Hughes, 2001), and individual differences in the regulation of emotions (action- (resulting from a circumstance) versus state- (a persistent feeling) oriented individuals) provide for vastly different shopping behaviors including responses to environmental stimuli (Babin \& Darden, 1995).

Emotions are also a large part of post consumption evaluations of goods and services (e.g., purchasing a vintage game souvenir several years after the game was played). Indeed, while satisfaction is not an emotion as such, recent definitions of consumer satisfaction suggest that it is a summary affective response of varying intensity to consumption experiences (Giese \& Cote, 2000). Models of consumer satisfaction include positive affect as increasing satisfaction and negative affect as decreasing satisfaction (Mano \& Oliver, 1993); also, higher levels of happiness, contentment, and delight are associated with higher levels of absolute satisfaction (Westbrook \& Oliver, 1991). However, other researchers suggest that there may be multiple roles for consumption emotions in postpurchase satisfaction, in that satisfaction may be unaffected by negative emotions if the service provider is not at fault (Dube \& Menon, 2000). These consumer-related findings highlight the complexities of general emotions and emotional dimensions within consumer decision processes. 
Investigations into emotions in consumption activities have used and compared emotional models proposed by Mehrabian and Russell (1974) and Plutchik (1980). While no conclusive evidence exists as to the superiority of these approaches, Mehrabian and Russell's (1974) three-dimensional model of pleasure, arousal, and dominance (PAD) may be deemed as a more reliable and valid measure of emotions in consumption experiences (Havlena \& Holbrook, 1986), and may be more robust in describing emotions in consumer activities versus responses to words (Havlena, Holbrook, \& Lehmann, 1989). For example, fans' PAD emotions may antecede their intentions to attend games and purchase memorabilia as these contexts are ripe for generating emotional responses.

\section{Segmented Lineage Theory}

Research suggests that fans buy and wear team-related merchandise as a means to publicize their attachment to a winning team (Cialdini, Borden, Thorne, Walker, Freeman, \& Sloan, 1976; Cialdini \& Richardson, 1980), which suggests that individuals manage their public image by purchasing items that associate themselves with winners. However, it is not far-fetched, assuming travel time and expenses are not excessive, to suggest that, in addition to supporting a successful or liked team, that fans attend games involving their least favorite team to root against them or to experience the pleasure in watching them lose. To help explain this phenomenon, we turn to an anthropological theory, segmentary lineage (Sahlins, 1961), as an explanation for game attendance where a least favorite team is involved.

Sahlins (1961) proposed a theory of segmented lineage to explain the predatory behavior of tribes, where tribes are more energized by threat or opposition than by cohesive political or social structure. According to Sahlins (1961), tribes have six basic characteristics, which we argue also are found in fans of collegiate football teams. First, lineage or common threads bind segments of the tribe together much as cohorts and generations of university students are bound together. Second, the segments of the tribe can be easily identified such as those from different college or university fan bases. Third, tribes may have limited sociability; the common thread that binds them allows them to coexist in relative harmony without a permanent social structure in place, such as alumni that socialize rarely except when attending college football games with other alumni.

The fourth aspect suggests that when in competition, there is a tribal massing effect, where any opposition between groups extends automatically to any and all members of other tribes (e.g., the enmity aroused in an Auburn fan by seeing an Alabama fan wearing an Alabama t-shirt the week of the Iron Bowl). Fifth, there is structural relativity in which the contestants are essentially peer groups with similar structure and membership, such as when fans use the term "we" when they speak of their favorite team (Cialdini et al., 1976). Lastly, tribes see themselves as having no boundaries or limitations imposed by other social structures. Hence, avid fans can suspend social norms, paint their hair and bodies their favorite team's colors, and be admired and cheered by other spectators, where normally such behavior would be considered atypical. 


\section{Study 1}

\section{Hypotheses}

Emotions are inherent across sports contexts (e.g., individual and team, aggressive and nonaggressive) (Goldstein \& Iso-Ahola, 2008; Raynaud \& Bolos, 2008; Wann, Grieve, Zapalac, \& Pease, 2008b) and have the capacity to influence sports-related consumer behavior (Swanson et al., 2003). In addition, team identification, which may be based on emotional attachment (e.g., loyalty and fanaticism), is an important driver of game attendance (Koo \& Hardin, 2008) and team-licensed apparel purchases (Kwon, Trail, \& James, 2007). In concert with Holbrook et al. (1984), it is plausible to suggest that the PAD three-dimensional measure of emotions (Mehrabian \& Russell, 1974) may help explain fans' willingness to attend college football games involving their favorite team, as well as their intentions to purchase apparel and memorabilia of this beloved team. For example, pleasure (e.g., content with a favorite team), arousal (e.g., frenzied during a favorite team's game), and dominance (e.g., fans' emotions being influenced by a rival game approaching) emotions may affect fans' sports-related consumption tendencies.

According to social identity theory (Tajfel \& Turner, 1985), members of a social group (e.g., Nebraska football fans) identify with that group, view themselves as representative of that group, and model their attitudes, emotions, and behaviors accordingly. These attitudes in turn, solidify group membership, helping to define that group's unique position in society (Reed, 2002; Tajfel, 1978; Tajfel \& Turner, 1985). Emotions and sports team membership relate positively (Bizman \& Yinon, 2002; Gaunt, Sindic, \& Leyens, 2005; Weisbuch \& Ambady, 2008), which can influence individual behavior and perceived well-being (Wann, Brame, Clarkson, Brooks, \& Waddill, 2008a); when this membership entails following a collegiate football team, these emotions can influence decisions such as game attendance, as well as apparel and memorabilia purchases. To explore these relationships, we examine each of the three PAD emotional dimensions as antecedents of fans' college football-related consumption for a favorite team, with the following sets of hypotheses:

\section{Set 1}

H1a: Fans' pleasure emotional response toward their favorite team relates positively to their willingness to attend games involving this team.

H1b: Fans' arousal emotional response toward their favorite team relates positively to their willingness to attend games involving this team.

H1c: Fans' dominance emotional response toward their favorite team relates positively to their willingness to attend games involving this team.

\section{Set 2}

H2a: Fans' pleasure emotional response toward their favorite team relates positively to their willingness to purchase this team's apparel.

H2b: Fans' arousal emotional response toward their favorite team relates positively to their willingness to purchase this team's apparel.

H2c: Fans' dominance emotional response toward their favorite team relates positively to their willingness to purchase this team's apparel. 


\section{Set 3}

H3a: Fans' pleasure emotional response toward their favorite team relates positively to their willingness to purchase this team's memorabilia.

H3b: Fans' arousal emotional response toward their favorite team relates positively to their willingness to purchase this team's memorabilia.

H3c: Fans' dominance emotional response toward their favorite team relates positively to their willingness to purchase this team's memorabilia.

\section{Methodology}

Scale Descriptions. The survey contained questions from six scales: willingness to purchase apparel (4 items), willingness to purchase memorabilia (4 items), willingness to attend games (4 items), and the PAD three-dimensional framework-pleasure ( 8 items), arousal (4 items), and dominance (4 items). Scale items are provided in Table 1 . These scales are briefly described.

Willingness to: Purchase Apparel, Purchase Memorabilia, and Attend Games. Holmes and Crocker (1987) evaluated consumer purchase intentions for both high and low involvement products, and Mackenzie, Lutz, and Belch (1986) examined the relationship between advertising effectiveness and purchase intentions. Items were adapted from these two studies to create 4-item, seven-point semantic differential scales to measure fans' willingness to purchase apparel and memorabilia of, and to attend college football games involving their favorite team. Specifically, respondents were asked to indicate their intentions (e.g., not very likely/very likely, unwilling/willing) to purchase apparel, buy memorabilia, and attend games of their favorite collegiate football team.

PAD Framework. Mehrabian and Russell (1974) examined emotions as a discrete but continuous three-dimensional process (Havlena \& Holbrook, 1986). The pleasure dimension describes the valence of the felt emotion or emotional state as positive or negative (e.g., unfavorable vs. favorable). To capture the pleasure emotional dimension, respondents were asked to indicate how they feel toward their favorite collegiate football team (e.g., annoyed/pleased). The arousal dimension pertains to the action-orientation of the emotion (e.g., calm vs. excited), where the emotion is experienced as a result of a consumer circumstance, like attending a college football game. To capture the arousal emotional dimension, respondents were asked to indicate the level of intensity they feel toward their favorite collegiate football team (e.g., sluggish/frenzied). The dominance dimension refers to the emotion's control over the thoughts and behaviors of the individual for the duration of the emotion (e.g., controlled vs. controlling). To capture the dominance emotional dimension, respondents were asked to indicate the level of dominance they feel toward their favorite collegiate football team (e.g., guided/autonomous). The PAD framework yielded a 16-item, three-dimensional, seven-point semantic differential scale.

Data Collection Procedure. Undergraduate business students at a non-FBS southwest U.S. university were solicited as respondents during regularly scheduled classes. At the beginning of the questionnaire, students were asked if they were college football fans; students indicating no were excluded from study 


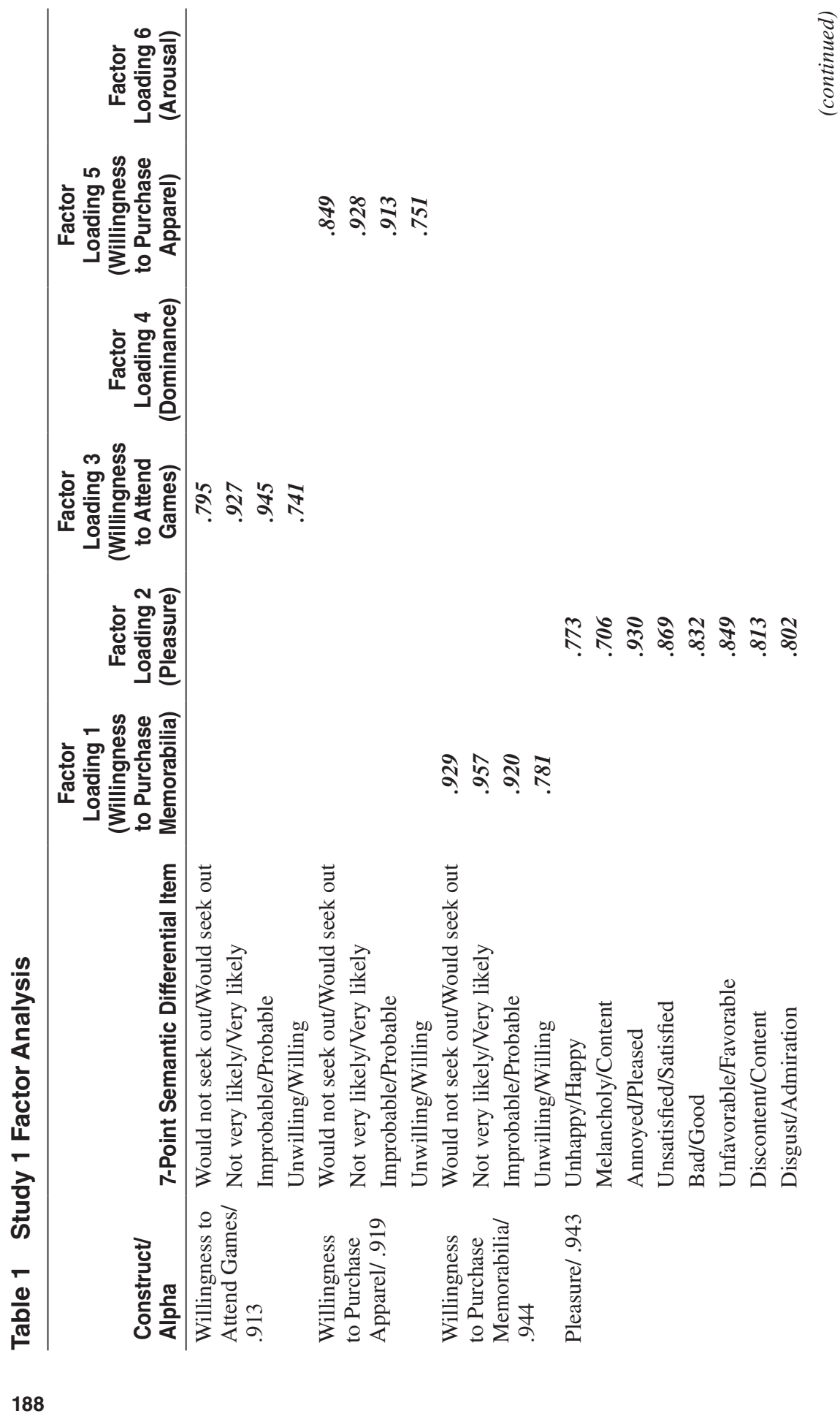




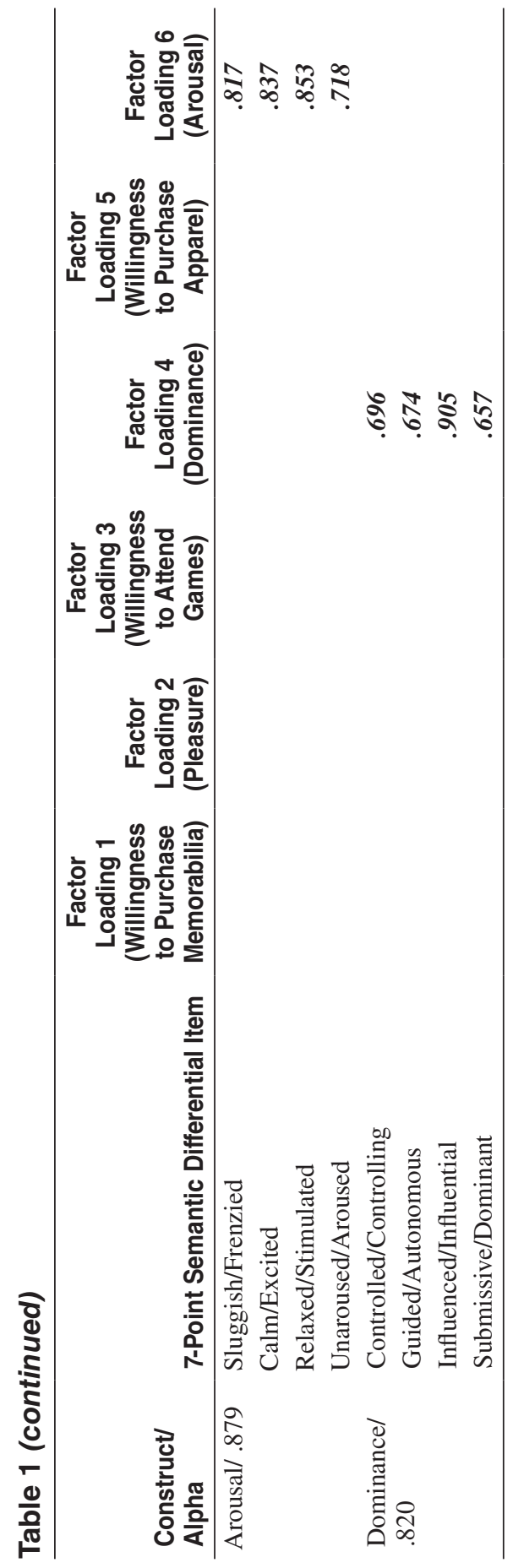


participation. Respondents indicating yes were then asked to specify their favorite college football team and how long in terms of years $\left(\mathrm{M}_{\mathrm{FAV}}=9.73\right.$ years, $S D=$ 6.39), they have felt this way. Subsequently, study participants answered sevenpoint semantic differential scale items for the studied constructs. Students were made aware that there were no right or wrong answers and that their responses were anonymous. During debriefing, the research method was critiqued and implications of the model were discussed. To compensate for participation, students received course extra credit in the form of $5 \%$ added to a designated exam that was worth $12 \%$ of their overall course grade.

Sample Profile. The sample size was 174 . The mean age of respondents was $21.57(S D=2.05)$ and males $(64 \%)$ outnumbered females. Whites $(74 \%)$ and Hispanics $(17.3 \%)$ were the main ethnic groups queried. Regarding class rank, juniors $(45.3 \%)$ and seniors $(33.7 \%)$ were most represented. Concerning respondents' favorite team, Texas $(55.2 \%)$, Texas A\&M (8.6\%), Texas Tech (5.7\%), Florida $(3.4 \%)$, and LSU $(2.9 \%)$ were most revered.

\section{Results}

Factor Structure. Maximum likelihood estimation with direct oblimin rotation was used to assess the factor structure of the 28 items that comprised the six scales. Missing data were handled with pairwise deletion. The resulting six factor solution (see Table 1), in which each item loaded highly on the appropriate factor (i.e., greater than 0.656 ) with no meaningful cross loadings (i.e., 0.583 or less), accounted for $77.33 \%$ of the variance. Reliabilities for the six scales ranged from $\mathrm{a}=0.820-0.944$.

Hypotheses Tests. Regression analysis was used to test the hypotheses, using the PAD emotional dimensions as predictors of game attendance and willingness to purchase apparel and memorabilia; the data revealed partial support for the posited relationships (see Table 2). Regarding H1, only fans' arousal emotional dimension ( $\mathrm{H} 1 \mathrm{~b}$ ) was significantly related to their willingness to attend games involving their favorite team. Pleasure (H1a) and dominance $(\mathrm{H} 1 \mathrm{c})$ were not significantly related to fans' willingness to attend their favorite team's games. A plausible explanation for the nonsignificant valence or pleasure-related finding is that the action-oriented emotion of arousal is more robust than the emotional state of pleasure regarding fans' favorite football teams; hence, emotional responses associated with arousal from attending a game of a favorite team for example, are stronger predictors of fan behavior than the persistent affect fans have toward their favorite team. The nonsignificant dominance-related finding may be explained by fans leaning more on and wanting to experience arousal regarding their favorite team than permit their emotions to dominate their thoughts and behaviors regarding their favorite team. Perhaps then, fans suppress intense negative emotions that linger, such as when a fan can't get over a heartbreaking loss, and accentuate arousal-related emotions directed toward their beloved team. 


\section{Table 2 Study 1 Regression Results}

\begin{tabular}{|c|c|c|c|}
\hline Hypothesis & $\begin{array}{c}\text { Beta } \\
\text { (Standardized) }\end{array}$ & $t$ value & $\begin{array}{l}\text { Significance } \\
\text { level }\end{array}$ \\
\hline $\begin{array}{l}\text { H1a: Pleasure is related positively to will- } \\
\text { ingness to attend games. }\end{array}$ & .116 & 1.32 & $\mathrm{NS}$ at $\mathrm{P}<0.05$ \\
\hline $\begin{array}{l}\text { H1b: Arousal is related positively to will- } \\
\text { ingness to attend games. }\end{array}$ & .304 & 3.44 & $\mathrm{P}<0.01$ \\
\hline $\begin{array}{l}\text { H1c: Dominance is related positively to } \\
\text { willingness to attend games. }\end{array}$ & -.039 & -.483 & $\mathrm{NS}$ at $\mathrm{P}<0.05$ \\
\hline \multicolumn{4}{|l|}{$\mathrm{F}(3,154)=7.83, \mathrm{P}<0.01$, Adjusted $R^{2}=.116$} \\
\hline $\begin{array}{l}\text { H2a: Pleasure is related positively to will- } \\
\text { ingness to purchase apparel. }\end{array}$ & .163 & 2.03 & $\mathrm{P}<0.05$ \\
\hline $\begin{array}{l}\mathrm{H} 2 \mathrm{~b} \text { : Arousal is related positively to will- } \\
\text { ingness to purchase apparel. }\end{array}$ & .428 & 5.33 & $\mathrm{P}<0.01$ \\
\hline $\begin{array}{l}\text { H2c: Dominance is related positively to } \\
\text { willingness to purchase apparel. }\end{array}$ & .020 & 0.27 & $\mathrm{NS}$ at $\mathrm{P}<0.05$ \\
\hline \multicolumn{4}{|l|}{$\mathrm{F}(3,153)=20.50, \mathrm{P}<0.01$, Adjusted $R^{2}=.273$} \\
\hline $\begin{array}{l}\text { H3a: Pleasure is related positively to will- } \\
\text { ingness to purchase memorabilia. }\end{array}$ & -.069 & -.846 & NS at $\mathrm{P}<0.05$ \\
\hline $\begin{array}{l}\text { H3b: Arousal is related positively to will- } \\
\text { ingness to purchase memorabilia. }\end{array}$ & .450 & 5.50 & $\mathrm{P}<0.01$ \\
\hline $\begin{array}{l}\mathrm{H} 3 \mathrm{c} \text { : Dominance is related positively to } \\
\text { willingness to purchase memorabilia. }\end{array}$ & .199 & 2.68 & $\mathrm{P}<0.01$ \\
\hline $\mathrm{F}(3,153)=18.01, \mathrm{P}<0.01$, Adjusted $R^{2}=.246$ & & & \\
\hline
\end{tabular}

Regarding $\mathrm{H} 2$, both fans' pleasure (H2a) and arousal (H2b) emotional dimensions were significantly related to their intentions to purchase their favorite team's apparel; however, fans' dominance emotional dimension (H2c) was not significantly related to their willingness to purchase their favorite team's apparel. Thus, state- (pleasure) and action-oriented (arousal) emotions are stronger predictors of collegiate football apparel purchases than dominance-related (e.g., controlling) emotions. In this sense, fans appear likely to buy apparel during the week or weeks leading up to a game, as pleasure-related emotions are consistently directed at a loved team, or during a game, as aroused emotions toward a loved team are intensified, than after their favorite team endures a tough loss and controlling emotions ensue.

Regarding H3, both fans' arousal (H3b) and dominance (H3c) emotional dimensions related significantly to their intentions to purchase their favorite team's memorabilia; however, fans' pleasure emotional dimension (H3a) was not significantly related to their willingness to purchase their favorite team's memorabilia. It appears that memorabilia purchases are made more in remembrance of the occasion 
(e.g., an "I was there" mentality) where fan excitement and influential emotions were evident from a favorable outcome or memorable game (e.g., Nebraska's triumph over Miami in the 1994 Orange Bowl), than because of fans' persistent affect toward a favorite team.

\section{Study 2}

To offer additional insight to Study 1, we examined emotional determinants of sport consumption involving loathed teams, which previous research has scarcely investigated. One exception found that National Basketball Association fans will watch a disliked team on television when they are deemed a threat to their favorite team or when they are likely to lose (Mahony \& Moorman, 1999). We build on these findings by examining the PAD emotional dimensions as antecedents of fans' intentions to attend games involving their least favorite collegiate football team, which previous research on intercollegiate sport has left unexplored.

\section{Hypotheses}

The relevance of emotions within sport consumption contexts is apparent (Koo \& Hardin, 2008; Preuss, 2007; Swanson et al., 2003), and as Study 1 indicates, the PAD emotional framework (Mehrabian \& Russell, 1974) is no exception. Hence, we expect the explanatory power of this three-dimensional framework to remain robust when used to explain consumer intentions to attend games involving their least favorite collegiate football team. For example, pleasure (e.g., satisfied in disliking a least favorite team), arousal (e.g., frenzied from watching a reviled team lose), and dominance (e.g., influenced by the emotions directed at a disliked rival) emotions have the capacity to influence fans' willingness to attend games in which this team is competing; therefore, we posit with the following three hypotheses that PAD emotions, when directed at abhorrent teams, will positively influence fans' willingness to attend this team's games.

H4a: Fans' pleasure emotional response toward their least favorite team relates positively to their willingness to attend games involving this team.

H4b: Fans' arousal emotional response toward their least favorite team relates positively to their willingness to attend games involving this team.

H4c: Fans' dominance emotional response toward their least favorite team relates positively to their willingness to attend games involving this team.

\section{Methodology}

Scale Descriptions. The survey included questions from four scales: willingness to attend games (4 items), and the PAD three-dimensional framework-pleasure (8 items), arousal (4 items), and dominance (4 items). All scales were adapted from those used in Study 1 (see Table 3); the willingness to attend games measure was modified and asked respondents to indicate their intentions (e.g., not very likely/very likely, unwilling/willing) to attend games involving their least favorite collegiate football team to root against them or to watch them lose. 


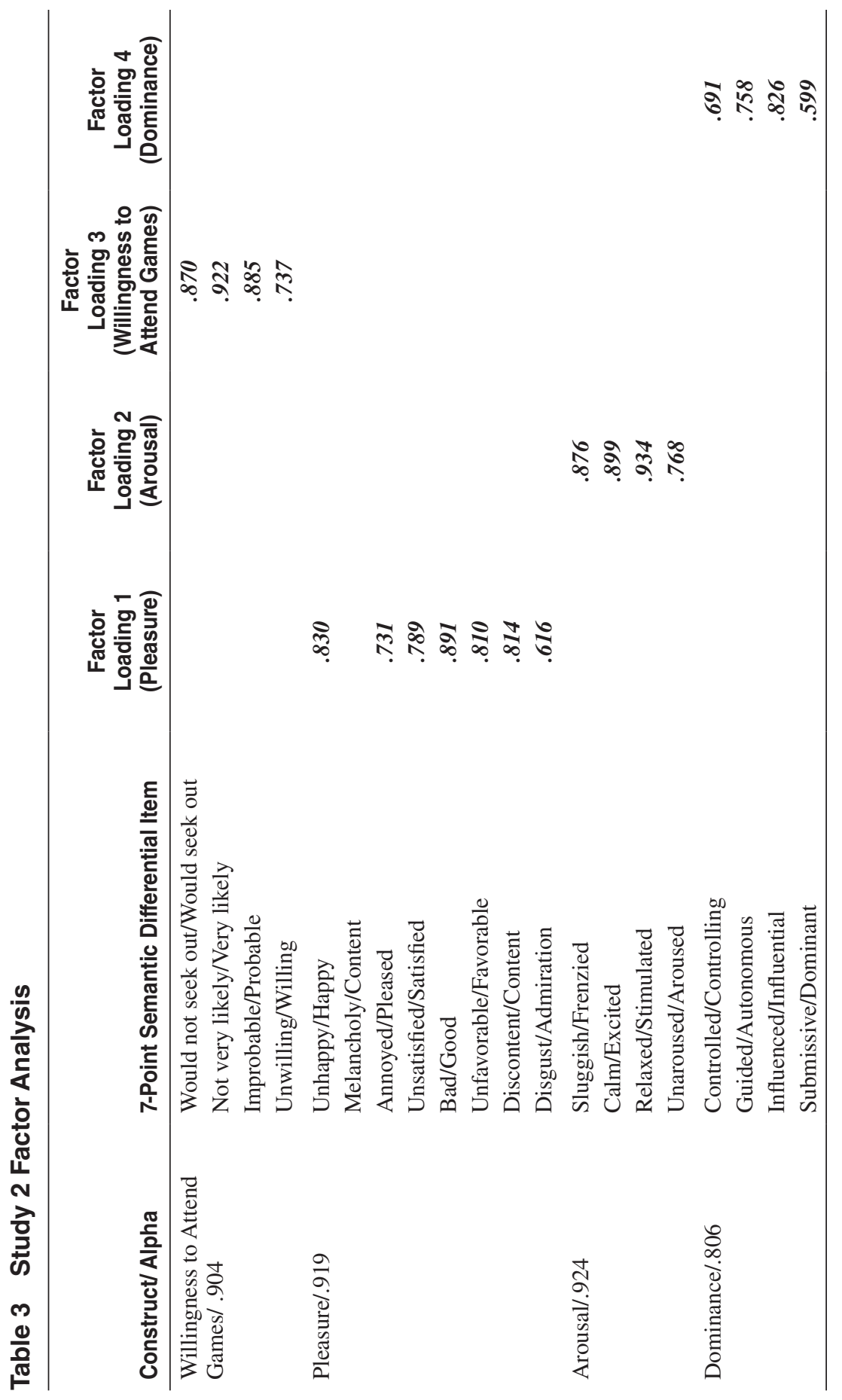


Data Collection Procedure. Undergraduate business students, who did not partake in Study 1, at a non-FBS southwest U.S. university were sought for study participation during regularly scheduled classes. At the beginning of the questionnaire, students were asked if they were college football fans; students who indicated no were precluded from the study. Respondents answering yes were then asked to indicate their least favorite college football team and how long in terms of years they have felt this way $\left(\mathrm{M}_{\text {LEASTFAV }}=9\right.$ years, $\left.S D=6\right)$. Subsequently, students answered seven-point semantic differential scale items about the studied constructs. Students were made aware that there were no right or wrong answers and that their responses were anonymous. Subsequent of completing the surveys, a debriefing session ensued where the research method was critiqued and implications of the model discussed. For their efforts, students received course extra credit in the form of $5 \%$ added to a designated exam that was worth $12 \%$ of their overall course grade.

Sample Profile. The sample size was 155 , the mean age was $21.85(S D=2.4)$, and males $(66.7 \%)$ outnumbered females. Whites $(76.7 \%)$ and Hispanics $(14 \%)$ comprised the majority of ethnic groups studied. In terms of class standing, juniors $(37.8 \%)$ and seniors $(36.5 \%)$ were most prominent. Regarding teams loathed, Texas A\&M (21.9\%), Oklahoma (21.3\%), Texas (11\%), Texas Tech $(9 \%)$, and USC $(8.4 \%)$ were least regarded.

\section{Results}

Factor Structure. Maximum likelihood estimation with direct oblimin rotation was used to assess the factor structure of the 20 items that comprised the four scales. Pairwise deletion was used for missing data. The resulting four factor solution (see Table 3), in which each item loaded highly on the appropriate factor (i.e., greater than 0.598 ) with no meaningful cross loadings (i.e., 0.395 or less), accounted for $71.54 \%$ of the variance. Reliabilities for the four scales ranged from $\mathrm{a}=0.806-0.924$.

Hypotheses Tests. Regression analysis was employed to test the hypotheses, using the PAD emotional dimensions as predictors of game attendance; the data revealed support at the $p<.05$ level or better for proposed relationships (See Table 4). Specifically, fans' emotional responses of pleasure (H4a), arousal (H4b), and dominance

\section{Table 4 Study 2 Regression Results}

\begin{tabular}{lccc}
\hline Hypothesis & $\begin{array}{c}\text { Beta } \\
\text { (Standardized) }\end{array}$ & t value & $\begin{array}{c}\text { Significance } \\
\text { level }\end{array}$ \\
\hline $\begin{array}{l}\text { H4a: Pleasure is related positively to will- } \\
\text { ingness to attend games. }\end{array}$ & .354 & 4.85 & $\mathrm{P}<0.01$ \\
$\begin{array}{l}\text { H4b: Arousal is related positively to will- } \\
\text { ingness to attend games. }\end{array}$ & .277 & 3.68 & $\mathrm{P}<0.01$ \\
$\begin{array}{l}\text { H4c: Dominance is related positively to } \\
\text { willingness to attend games. }\end{array}$ & .164 & 2.21 & $\mathrm{P}<0.05$ \\
$\mathrm{~F}(3,137)=18.49, \mathrm{P}<0.01$, Adjusted $R^{2}=.273$ & & & \\
\hline
\end{tabular}


(H4c) toward their least favorite college football team related positively to their willingness to attend games featuring this loathed team. Hence, fans' PAD emotions toward their least favorite team positively influenced their intentions to be in attendance during this team's games.

\section{Discussion}

Although prior sports research offers important insight to sport consumption, research has yet to explore Mehrabian and Russell's (1974) PAD emotional dimensions as determinants of fan purchase intentions for loved and loathed collegiate football teams. As such, the preliminary studies here add to our knowledge of emotional drivers of college football game attendance and purchase intentions of collegiate football products. For example, results from Study 1 indicate that for fans' favorite team, the arousal emotional dimension relates positively to intentions to attend games involving this team. Win or lose, fans love their teams wholeheartedly, so perhaps it is not entirely surprising that the pleasure and dominance emotional dimensions are not significantly related to game attendance. It is the excitement associated with watching a favorite team play that leads fans to be in attendance.

Study 2 shows that the pleasure, arousal, and dominance emotional dimensions associated with a fan's least favorite team are positively related to willingness to attend games involving this team. In such instances, the persistent dislike toward, intense desire to watch a loss, and the thrill of rooting against a bitter rival are grounded, as we suggest, in segmented lineage theory; as such, fans of a team band together to enjoy each other's company and to root against a loathed foe. By specifying the emotional benefits and effects associated with perceived fan "tribal" membership with collegiate football teams, our findings offer meaningful insight to prior sports studies examining effects of fan emotions on team identification (Hirt, Zillman, Erickson, \& Kennedy, 1992), eustress on game attendance (Swanson et al., 2003), and team success and emotional response (Tesser, 1988).

Study 1 results also indicate a significant positive effect for the arousal emotional dimension on fans' intentions to purchase their favorite team's apparel and memorabilia. In addition, the pleasure and dominance emotional dimensions are positive and significantly related to fans' purchase intentions of their favorite team's apparel and memorabilia, respectively. Thus, the excitement associated with an adored team, which may be rooted in fans' ability to associate and identify with this team, leads to apparel and memorabilia purchases. In addition, emotional pleasure (e.g., a persistent liking for a team) persuades fans to buy their favorite team's apparel, while the dominance of the emotion (e.g., influential affect stemming from a memorable event) encourages the acquisition of memorabilia in remembrance of the occasion. These findings suggest that PAD emotional dimensions when directed at favorite collegiate football teams lead to heightened levels of team-related product purchases, and further validate the importance of emotions within a hedonic-laden consumption context (Hirschman \& Holbrook, 1982).

\section{Implications}

In general, our findings suggest that fans get excited at the prospect of their favorite team winning; however, the prospect of their least favorite team losing brings out 
a full range of emotional responses as well, and contributes to sport consumption. Our research suggests that the dimensions of fans' emotional makeup are driving specific aspects of collegiate football consumption. Fans always love their team; thus, the positive valence of their emotions seemingly does not contribute to game attendance, yet the prospect of being with fellow fans and the ensuing game excitement strongly encourages game attendance. It also appears that fans buy their favorite team's apparel, at least partially, according to the excitement and intense emotions aroused by team events, and they acquire memorabilia as a result of dominant-laden emotions after a thrilling win or momentous occasion.

Sports promoters have been highlighting admiration and excitement for venerated teams for some time. Our study suggests extending emotional appeals to rival teams as well (e.g., stressing an us versus them mentality). Local rivalries are wellknown enhancers of live game attendance (Paul, 2003); our findings suggest that emotional factors highly motivate fans to attend college football games involving foes. Therefore, sports marketers should work on building support and admiration for the favorite local team, which may lead to an increase importance placed on rivalry games. Such communicative strategies should accentuate the emotions (e.g., excitement) associated with attending collegiate football games to cheer for a favorite team and root against rivals, while enjoying intercollegiate competition. In doing so, as our findings suggest, an increase in sport-related purchases may ensue.

\section{Limitations and Future Research}

Our research is not without limitations. First, business student samples from a southwest university provided data about their favorite and least favorite college football team. Collecting additional data in various regions, with nonbusiness students or nonstudent samples, for sundry teams across multiple sports would help generalize the findings (Winer, 1999). Second, the scales used to measure the studied constructs may not be equally valid across various samples (e.g., adult fans) and sport contexts (e.g., intercollegiate basketball), which may affect the measurement properties of the underlying constructs and their relationships with one another. Third, aside from the paper-and-pencil method we employed, additional data collection techniques (e.g., football stadium intercepts, online panels) are needed to help validate our findings.

To provide further insight into fans' responses to collegiate sports, additional variables could be examined; for example, psychographic determinants of sport purchases could be investigated, including self image (Cialdini \& Richardson, 1980), attitude toward the head coach, anticipated emotions about a team winning or losing, locus of control about game outcomes, and fan self-reported competence and expertise about a particular team and sports program. The situational context also may play a role in fans' emotional response to sports and teams. For example, emotional response about attending a game may be higher for a home versus an away rivalry game or for college football teams, which play roughly 13 games per season compared with college basketball teams that play roughly 30 games per season.

Alternative research tools, such as experiments and interpretive methods, could be used to examine the effects of emotions on sports-related purchases. The impact of social media and networks on collegiate sport transactions warrants inquiry (Wakefield, 1995), as does the examination of memory effects and feelings of nostalgia 
(Sierra \& McQuitty, 2007) on emotion-laden collegiate sport purchases. Finally, other researchers have noted the community affiliation propensities of sports fans (Sutton, MacDonald, Milne, \& Cimperman, 1997); our study suggests that additional research could examine "we/they" (Cialdini et al., 1976) emotional expression and response within other sporting venues such as television viewing and sports bars.

\section{References}

Babin, B., \& Darden, W.R. (1995). Consumer self-regulation in a retail environment. Journal of Retailing, 71, 47-70.

Bizman, A., \& Yinon, Y. (2002). Engaging in distancing tactics among sports fans: Effects on self-esteem and emotional responses. The Journal of Social Psychology, 142, 381-392.

Cialdini, R.B., Borden, R.J., Thorne, A., Walker, M.R., Freeman, S., \& Sloan, L.R. (1976). Basking in reflected glory: Three (football) field studies. Journal of Personality and Social Psychology, 34, 366-375.

Cialdini, R.B., \& Richardson, K.D. (1980). Two indirect tactics of image management: Basking and blasting. Journal of Personality and Social Psychology, 39, 406-415.

Dube, L., \& Menon, K. (2000). Multiple roles of consumption emotions in post-purchase satisfaction with extended service transactions. International Journal of Service Industry Management, 11, 287-299.

Elster, J. (1998). Emotions and economic theory. Journal of Economic Literature, 36, 47-74.

Fisher, R.J. (1998). Factors leading to group identification: A field study of winners and losers. Psychology and Marketing, 15, 23-40.

Fowler, D. (1999). The attributes sought in sports apparel: A ranking. Journal of Marketing Theory and Practice, 7, 81-88.

Funk, D.C., \& James, J. (2001). The psychological continuum model: A conceptual framework for understanding an individual's psychological connection to sport. Sport Management Review, 4, 119-150.

Funk, D.C., Mahony, D.F., \& Ridinger, L.L. (2002). Characterizing consumer motivation as individual difference factor: Augmenting the sport interest inventory (SII) to explain level of spectator support. Sport Marketing Quarterly, 11, 33-43.

Gaunt, R., Sindic, D., \& Leyens, J-P. (2005). Intergroup relations in soccer finals: People's forecasts of the duration of emotional reactions of in-group and out-group soccer fans. The Journal of Social Psychology, 145, 117-126.

Giese, J.L., \& Cote, J.A. (2000). Defining consumer satisfaction. Academy of Marketing Science, 1, available at: http://www.amsreview.org/articles/giese01-2000.pdf.

Goldstein, J.D., \& Iso-Ahola, S.E. (2008). Determinants of Parents' Sideline-Rage Emotions and Behaviors at Youth Soccer Games. Journal of Applied Social Psychology, $38,1442-1462$.

Havlena, W.J., \& Holbrook, M.B. (1986). The varieties of consumption experience: Comparing two typologies of emotions in the consumption experience. The Journal of Consumer Research, 13, 394-404.

Havlena, W.J., Holbrook, M.B., \& Lehmann, D.R. (1989). Assessing the validity of consumption typologies. Psychology and Marketing, 6, 97-112.

Hill, B., \& Green, B.C. (2000). Repeat attendance as a function of involvement, loyalty, and the sportscape across three football contexts. Sport Management Review, 3, 145-162.

Hirschman, E.C., \& Holbrook, M.B. (1982). Hedonic consumption: Emerging concepts, methods and propositions. Journal of Marketing, 46, 92-101.

Hirt, E.R., Zillman, D., Erickson, G.A., \& Kennedy, C. (1992). Costs and benefits of allegiance: Changes in fans' self-ascribed competencies after team victory versus defeat. Journal of Personality and Social Psychology, 63, 724-738. 
Holbrook, M.B., Chestnut, R.W., Oliva, T.A., \& Greenleaf, E.A. (1984). Play as a consumption experience: The roles of emotions, performance, and personality in the enjoyment of games. The Journal of Consumer Research, 11, 728-739.

Holbrook, M.B., \& Hirschman, E.C. (1982). The experiential aspects of consumption: Consumer fantasies, feelings, and fun. The Journal of Consumer Research, 9, 132-140.

Holmes, J.H., \& Crocker, K.E. (1987). Predispositions and the comparative effectiveness of rational, emotional, and discrepant appeals for both high involvement and low involvement products. Journal of the Academy of Marketing Science, 15, 27-35.

Karayianni, D., \& Mylonakis, J. (2008). Buyer satisfaction, purchasing decision and relative contribution of promotion tools to Olympic products: The Athens 2004 experience. ICFAI Journal of Marketing Management, 7, 6-14.

Koo, G-Y., \& Hardin, R. (2008). Difference in interrelationship between spectator's motives and behavioral intentions based on emotional attachment. Sport Marketing Quarterly, 17, 30-43.

Kwon, H.H., Trail, G., \& James, J.D. (2007). The mediating role of perceived value: Team identification and purchase intention of team-licensed apparel. Journal of Sport Management, 21, 540-554.

Loewenstein, G.F., Weber, E.U., Hsee, C.K., \& Welch, N. (2001). Risk as feelings. Psychological Bulletin, 127, 267-286.

MacInnis, D.J., \& de Mello, G.E. (2005). The concept of hope and its relevance to product evaluation and choice. Journal of Marketing, 69, 1-14.

MacKenzie, S.B., Lutz, R.J., \& Belch, G.E. (1986). The role of attitude toward the ad as a mediator of advertising effectiveness: A test of competing explanations. Journal of Marketing Research, 23, 130-143.

Mahony, D.F., Madrigal, R., \& Howard, D. (2000). Using the psychological commitment to a team (PCT) scale to segment sport consumers based on loyalty. Sport Marketing Quarterly, 9, 15-25.

Mahony, D.F., \& Moorman, A.M. (1999). The impact of fans attitudes on intentions to watch professional basketball teams on television. Sport Management Review, 2, 43-66.

Mahony, D.F., Nakazawa, M., Funk, D.C., James, J.D., \& Gladden, J.M. (2002). Motivational factors influencing the behaviour of J. league spectators. Sport Management Review, 5, 1-24.

Mano, H., \& Oliver, R.L. (1993). Assessing the dimensionality and structure of the consumption experience: Evaluation, feeling, and satisfaction. The Journal of Consumer Research, 20, 451-466.

Matsuoka, H., Chelladurai, P., \& Harada, M. (2003). Direct and interaction effects of team identification and satisfaction on intention to attend games. Sport Marketing Quarterly, 12, 244-253.

Mehrabian, A., \& Russell, J.A. (1974). An approach to environmental psychology. Boston, MA: MIT Press.

Paul, R.J. (2003). Variations in NHL attendance: The impact of violence, scoring, and regional rivalries. American Journal of Economics and Sociology, 62, 345-364.

Pham, M.T. (2004). The logic of feeling. Journal of Consumer Psychology, 14, 360-369.

Pham, M.T., Cohen, J.B., Pracejus, J.W., \& Hughes, G.D. (2001). Affect monitoring and the primacy of feelings in judgment. The Journal of Consumer Research, 28, 167-188.

Plutchik, R. (1980). Emotion: An evolutionary synthesis. New York, NY: Harper and Row.

Preuss, H. (2007). The conceptualization and measurement of mega sport event legacies. Journal of Sport \& Tourism, 12, 207-227.

Raynaud, J., \& Bolos, G. (2008). Sport at the heart of marketing: The integration debate. Journal of Sponsorship, 2, 31-35.

Reed, A., II. (2002). Social identity as a useful perspective for self-concept-based consumer research. Psychology and Marketing, 19, 235-266. 
Robinson, M.J., Trail, G.T., Dick, R.J., \& Gillentine, A.J. (2005). Fans vs. spectators: An analysis of those who attend intercollegiate football games. Sport Marketing Quarterly, $14,43-53$.

Robinson, M.J., Trail, G.T., \& Kwon, H. (2004). Motives and points of attachment of professional golf spectators. Sport Management Review, 7, 167-192.

Russell, J.A., \& Mehrabian, A. (1977). Evidence for a three-factor theory of emotions. Journal of Research in Personality, 11, 273-294.

Ruth, J.A. (1996). It's the feeling that counts: Toward an understanding of emotion and its influence on the gift exchange process. In C. Otnes \& R. Beltramini (Eds.), Gift-giving: An interdisciplinary anthology (pp. 195-214). Bowling Green, OH: Bowling Green University Press.

Ruth, J.A., Otnes, C.C., \& Brunel, F.F. (1999). Gift receipt and the reformulation of interpersonal relationships. The Journal of Consumer Research, 25, 385-404.

Sahlins, M.D. (1961). The segmentary lineage: An organization of predatory expansion. American Anthropologist, 63, 332-345.

Sierra, J.J., \& McQuitty, S. (2007). Attitudes and emotions as determinants of nostalgia purchases: An application of social identity theory. Journal of Marketing Theory and Practice, 15, 99-112.

Sutton, W.A., MacDonald, M.A., Milne, G.R., \& Cimperman, J. (1997). Creating and fostering fan identification in professional sports. Sport Marketing Quarterly, 6, 15-22.

Swanson, S.R., Gwinner, K., Larson, B.V., \& Janda, S. (2003). Motivations of college student game attendance and word-of-mouth behavior: The impact of gender differences. Sport Marketing Quarterly, 12, 151-162.

Tajfel, H. (1978). Differentiation between social groups. New York, NY: Academic Press, Inc.

Tajfel, H., \& Turner, J.C. (1985). The social identity theory of group behavior. In S. Worchel \& W.G. Austin (Eds.), Psychology of intergroup relations (pp. 2, 7-24). Lanham, MD: Rowman \& Littlefield.

Tesser, A. (1988). Toward a self-evaluation maintenance model of social behavior. In L. Berkowitz (Ed.), Advances in experimental social psychology (Vol. 21, pp. 181-227). San Diego, CA: Academic Press.

Trail, G.T., Robinson, M.J., Dick, R.J., \& Gillentine, A.J. (2003). Motives and points of attachment: Fans vs. spectators in intercollegiate athletics. Sport Marketing Quarterly, 12, 217-227.

Wakefield, K.L. (1995). The pervasive effects of social influence on sporting event attendance. Journal of Sport and Social Issues, 19, 335-351.

Wann, D.L., Brame, E., Clarkson, M., Brooks, D., \& Waddill, P.J. (2008a). College student attendance at sporting events and the relationship between sport team identification and social psychological health. Journal of Intercollegiate Sports, 1, 242-254.

Wann, D.L., Grieve, F.G., Zapalac, R.K., \& Pease, D.G. (2008b). Motivational profiles of sport fans of different sports. Sport Marketing Quarterly, 17, 6-19.

Weisbuch, M., \& Ambady, N. (2008). Affective divergence: Automatic responses to others' emotions depend on group membership. Journal of Personality and Social Psychology, 95, 1063-1079.

Westbrook, R.A., \& Oliver, R.L. (1991). The dimensionality of consumption emotion patterns and consumer satisfaction. The Journal of Consumer Research, 18, 84-91.

Winer, R.S. (1999). Experimentation in the $21^{\text {st }}$ century: The importance of external validity. Journal of the Academy of Marketing Science, 27, 349-358. 